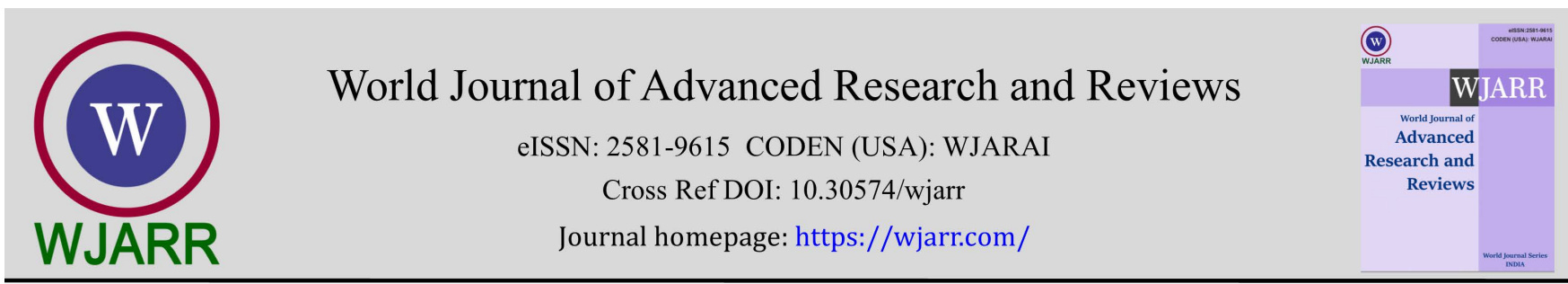

(RESEARCH ARTicle)

\title{
Enhancing rainfed wheat productivity through technology validation and dissemination in Nertiti locality of Central Darfur State-Sudan
}

\author{
Elkhalil Elnour Breima ${ }^{1,}{ }^{*}$, Amani Ahmed Idris ${ }^{2}$, Elhafiz Abdalla Haroon ${ }^{1}$, Aboh Adam Elnour ${ }^{1}$ and Ali \\ Ahmed Dawoud ${ }^{3}$

\begin{abstract}
${ }^{1}$ Agricultural Research Corporation, Zalingei Agricultural Research station, Zalingei-Sudan.
${ }^{2}$ National Wheat Coordinator, Agricultural Research Corporation, Gazera Research Station, Gazera-Sudan.

${ }^{3}$ Food and Agricultural Organization of the United Nations, Zalingei field office, Central Darfur state, Sudan.
\end{abstract}

World Journal of Advanced Research and Reviews, 2021, 09(03), 281-287

Publication history: Received on 04 February 2021; revised on 10March 2021; accepted on 12 March 2021

Article DOI: https://doi.org/10.30574/wjarr.2021.9.3.0082

\begin{abstract}
This research has been conducted in Nertiti locality of central Darfur State during 2020/2021 cropping season in order to enhance rainy wheat productivity through technology validation and dissemination. Farmers Field School was established with 25 farmers ( 5 men and 20 women). On-station demonstration farm was conducted with an area of 2 feddan. Improved wheat variety Zakia (1feddan) grown versus Nillin ( 0.5 feddan) and local ( 0.5 feddan) to evaluate crop performance and potentiality. Clustered random sampling technique applied. Evaluation questionnaires developed randomly to 20 farmers to know farmers perceptions on wheat performance and productivity. Farmers subjected to farming training in wheat technologies of land preparation, sowing date, seed preparation, seed dressing, weeding, water harvesting, soil conservation, pests and diseases control, seed production technologies and harvest and post harvest technologies. Results showed that excessive rainfall variation during reproductive growth affect wheat yield by $32 \%$. Socioeconomic characteristics and frequency distribution of farmers revealed that $80 \%$ of FFS participants were educated and $20 \%$ illiterate. $10 \%$ of farmers have farm size less than 1 feddan, $50 \%$ have $1-2$ feddan, $30 \%$ have farm size range between 3-4 feddan and 10\% have more than 4 feddan. Agriculture is the main source of income (80\%), while $20 \%$ traders and pity trading. Results noted that $90 \%$ of FFS participants have no extension services and only $10 \%$ have.40\% of respondent's have experience in wheat production, while 60 have no experience.40\% of participants perceived that improved wheat is resistant to water logging and high rain fall, $20 \%$ resist to insects, $30 \%$ high yielded and $10 \%$ said low yielded. Crop productivity trend showed that highest grain yield was obtained by improved Zakaia (655 kg/feddan) followed by Nillin ( $626 \mathrm{~kg} /$ feddan), while the lowest yield gained by local (424 kg/fedan). It was also recorded that improved Zakia exceed local and Nillin yields by $54 \%$ and $5 \%$, respectively. Partial crop budget result revealed that all treatments were financially gave positive net returns. Improved Zakia gave highest net returns (SDG 21,500), Nillin (SDG18, 900) and the lowest net returns obtained by local wheat (SDG 15,000). Study recommended training in wheat technologies and enhancing the role of research station in the study area.
\end{abstract}

Keywords: Dissemination; Frequency; Partial crop budget; Socioeconomic; Validation; Wheat

\section{Introduction}

The process of agricultural technology and growth has remained outside the concern of most development economists. The critical factor in raising productivity is 'technical change' and the role of the government is to promote technical change. Policy prescription was for the government to invest in agricultural research stations and in the provision of agricultural extension services. Schultz's approach argues about the important dimension that the process of agricultural development can be accelerated through provision of new and improved inputs and technologies

${ }^{*}$ Corresponding author: Elkhalil Elnour Breima

Agricultural Research Corporation, Zalingei Agricultural Research Station, Zalingei-Sudan.

Copyright (C) 2021 Author(s) retain the copyright of this article. This article is published under the terms of the Creative Commons Attribution Liscense 4.0. 
(particularly improved seeds, fertilizers, pesticides, and irrigation systems). What farmers need are new high-payoff inputs and technologies to increase their productivity [1].

Wheat is the most important food security crop at the global level with a production of 750 million tons (MT) on about 220 million hectares (Mha) in 2017. Africa produces more than 25 million tons of wheat on 10 Mha. Sub-Sahara Africa (SSA) produced a total of 7.5 MT on a total area of 2.9 Mha accounting for 40 and 1.4 per cent of the wheat production in Africa and at global levels, respectively [2]. Bread wheat, which accounts for 95 per cent of the wheat production at the global level, is also the dominant wheat type produced in SSA. Trend analysis of wheat production in SSA from 1970 to 2014 indicates that the total wheat production area showed slight reduction, while the total production has increased from 2.8 to 7.5 MT because of the increase in productivity of wheat from $1.3 \mathrm{t} /$ ha in 1970 to $2.1 \mathrm{t} /$ ha in 2014 . The most important wheat producing countries in SSA are Ethiopia, South Africa, Sudan, Kenya, Tanzania, Nigeria, Zimbabwe and Zambia in descending order. Ethiopia accounts for the largest production area (1.7 Mha) followed by South Africa (0.5 Mha). The increasing demand for wheat at global level, on the one hand, and the challenges facing wheat production such as climate change, increased cost of inputs, increased intensity of a biotic (drought, heat) and biotic (diseases and pests) stresses, on the other hand, make the wheat demand-supply chain very volatile and at times lead to social unrest. According to [3] agriculture is the main economic activity of the population in Central Darfur state, the majority of the population depends heavily on cereal crops production as a main source of Livelihood and income; they make use of their local knowledge to achieve food security. People cultivate many varieties of cereal crops in Central Darfur state; some were indigenous, while others were introduced. However, they cultivate a variety of cultivars of cereals, ranging from early maturing to late maturing, some were introduced by some institutions such as Jebel Marra Rural Development Project (JMRDP) or Ministry of Agriculture (Tabat and Wad Ahmed), some were entered from neighboring countries like (Subiansawa), while others were indigenous (Baladi, Faseikh, and Najjad). The local sorghum cultivars Baladi and Faseikh among others, are widely cultivated by the farmers in the area, as $53 \%$ of the farmers cultivate it in pure stand this can be attributed to the fact that, the soil in the study area is mainly of alluvial strata or flood plains (locally known as Wadi), where the crop can exploit the available soil moisture reserved during the wet and dry seasons. They are known to be late maturing cultivars. Other cultivars are usually grown in inter cropping system in most areas in marginal soils. Bayouda, Darmassa and Baladi are most millet cultivars cultivated by farmers, because they are known high yielding varieties. Local maize known, as Baladi is the most prevailing cultivar together with the cultivar; Americani, the later is an early maturing one. About $66 \%$ of the farmers grow local wheat cultivars known as Jabali, 33\% cultivate the newly introduced cultivar; Condor, mainly in Jebel Marra highlands. About 75\% of the farmers who grew rice cultivate the local cultivar; Sudani, while the rest cultivate the cultivar Baladi. According to the Global Crop Diversity Trust (GCDT), poor farmers are well aware of the relationship between the stability and sustainability of their production systems, and the diversity of crops, and crop varieties on their lands. Their management and use of a diverse range of plants has often helped them to survive under most difficult conditions. This diversity emphasizes that the farmer takes the advantage of cultivating different cultivars of cereals, as safeguard during adverse conditions, such as drought or invasion by pests, which is very common in the area. Cereals dominate crop production in Sudan provide nearly $53 \%$ of the population's daily calorie requirements (FAO-SIFSIA. 2010). The same high level of annual fluctuation as for other crops characterizes the production of the major staples -sorghum, millet and wheat. Before 1960, apart from small areas in Darfur and Kordofan, Sudan grow wheat only in the northern state, and even there only on limited scale. The production of cereals, sorghum, millet and wheat declined in 2010 by nearly $42 \%$ from to only 2.9 million metric tons. The magnitude of production decline varied by crop: 46.8 per cent for sorghum; 31.3 per cent for wheat; and 24.2 per cent for millet [5]. Agriculture is the main sources of income in central Darfur State. The main stable food crops grown by farmers are millet sorghum and wheat. Farmers cultivate rainy and irrigated wheat in the uplands of Jebel Marra and lowlands plains of Azum and Zalingei localities since the nineteen first where average rainfall range from $650-1100 \mathrm{~mm}$. The area under cultivation was estimated at that time by 3000 feddan (2200 rain fed and 800 irrigated lands). The major problems in the project villages are poverty, unemployment, failure of crops, heavy debts, no secondary income, lack of capital for investment and emergency needs, in addition to lack of knowledge and skills, lack of leadership, insufficient knowledge and skills in taking up feasible income generation programs, lack of awareness on mobilization and utilization of the locally available raw materials and natural resources, lack of marketing facilities and business skills etc. Due to all mentioned above people are living in low income level and economic status [4].

This study was designed to examine the rainy and irrigated wheat productivity with the application of production technologies in forms of technical packages at farmers' level.

On-farm research via demonstration farms aimed towards implementation of applied research on working farms to gather information, validation and disseminate of technologies to the grass root needed to ensure food security in the study area. Effective improved technologies can result in higher agricultural production and increased incomes of farming families, which may unequivocally have a positive impact on rural poverty levels. Increased crop yields will reduce costly imports of agricultural commodities and the cost of production of basic raw materials for agro-industries. 


\subsection{Goals and objectives}

The project goal is to ensure food security, while the specific objectives will be:-

- $\quad$ To introduce new improved technologies for ensuring farmers crop productivity

- $\quad$ To validate the performance of improved varieties of wheat against local varieties

- $\quad$ To strengthening the productive capacities of the small farmers

\subsection{Frequency distribution}

Frequency distribution is an organized tabulation/ graphical representation of the number of individuals in each category on the scale of measurement. It allows the researcher to have a glance at the entire data conveniently. It shows whether the observations are high or low and also whether they are concentrated in one area or spread out across the entire scale. Thus, frequency distribution presents a picture of how the individual observations are distributed in the measurement scale [6].

\subsection{Partial crop budget}

According to [8] a partial budget helps farm owners/managers evaluate the financial effect of incremental changes. A partial budget only includes resources that will be changed. It does not consider the resources in the business that is left unchanged. Only the change under consideration is evaluated for its ability to increase or decrease income in the farm business.

\section{Research methodology}

This study was conducted in Nertiti locality of Central Darfur State (CDS) during 2020/2021 rainy season. Clustered random sampling applied. Farmers Field School was established with 25 farmers (5 men and 20 women). Demonstration farm was conducted with an area of 2 feddan. Improved seeds variety Zakia grown versus Nillin and local to evaluate crop performance and potentiality. Farmers subjected to farming training in wheat technologies of land preparation, sowing date, seed preparation, seed dressing, weeding, water harvesting, soil conservation, pests and diseases control, seed production technologies, harvest and postharvest technologies. Knowledge also shared and disseminated by extension officers as partners representing ministry of production and economic resources. Evaluation questionnaires developed randomly to 20 farmers to know farmers perceptions on wheat performance and productivity. Partial crop budget run for cost benefit analysis and descriptive analysis adopted for frequency distribution.

\section{Results and discussion}

\subsection{Effect of monthly rain fall variability on wheat yield}

Rainfall variability trend was shown in figure 1 . The total rainfall along 2020/2021 cropping rainy season was 1037.5 $\mathrm{mm}$. the highest rainfall amount was recorded in August ( $474 \mathrm{~mm}$ ), followed by $357 \mathrm{~mm}$ in September, July $188 \mathrm{~mm}$, June $18 \mathrm{~mm}$ and the lowest rainfall recorded in may $(0.5 \mathrm{~mm})$. It was obvious and clearly observed that excessive rainfall during August and September affected and decreased wheat yield. This results entails that wheat require optimal and even distribution of rainfall to grow and produce better yield.

\subsection{Socioeconomic characteristics of farmers}

Results of socioeconomic characteristics of farmers revealed that $80 \%$ of FFS participants were educated and $20 \%$ illiterate. This highlighted that education expected to play a positive role in ensuring knowledge and understanding of wheat technologies. [7] farm size plays a critical role in agricultural sustainability. Statistical analysis showed that $10 \%$ of participants farmers have farm size less than 1 feddan, $50 \%$ between $1-2$ feddan, 30\% have farm size range between 3-4 feddan and 10\% have more than 4 feddan. $80 \%$ of farmers were practicing agriculture as main source of income and $20 \%$ of farmers/pity traders. Results noted that $90 \%$ of FFS participants have no extension services and only $10 \%$ have. Experience in agricultural farming is very important in crop management in general and particularly in wheat yield potentiality. $40 \%$ of respondent's have experience in wheat production, while 60 have no experience. This entails that intensive and quality training in wheat technical packages is recommended. $40 \%$ socioeconomic results of participants perceived that improved wheat is resistant to water logging and high rain fall, $20 \%$. Resist to insects, $30 \%$ high yielded and 10\% said low yielded, Table 1. 


\subsection{Crop productivity trend}

As shown in table 2 and figure 2, productivity trend indicated that the highest grain yield was obtained by improved Zakaia (655 kg/feddan) followed by Nillin (626 kg/feddan), while the lowest yield gained by local (424 kg/fedan). It was also recorded that improved Zakia exceed local and Nillin yields by 54\% and 5\%, respectively. These results ensured that improved Zakia has great yield potentiality in spite of higher rain fall, water logging and insect's damage.

\subsection{Partial crop budget}

Partial crop budget result revealed that all treatments were financially gave positive net returns. Improved Zakia gave highest net returns (SDG 21,500), Nillin (SDG18, 900) and the lowest net returns obtained by local wheat (SDG 15,000), Table 3

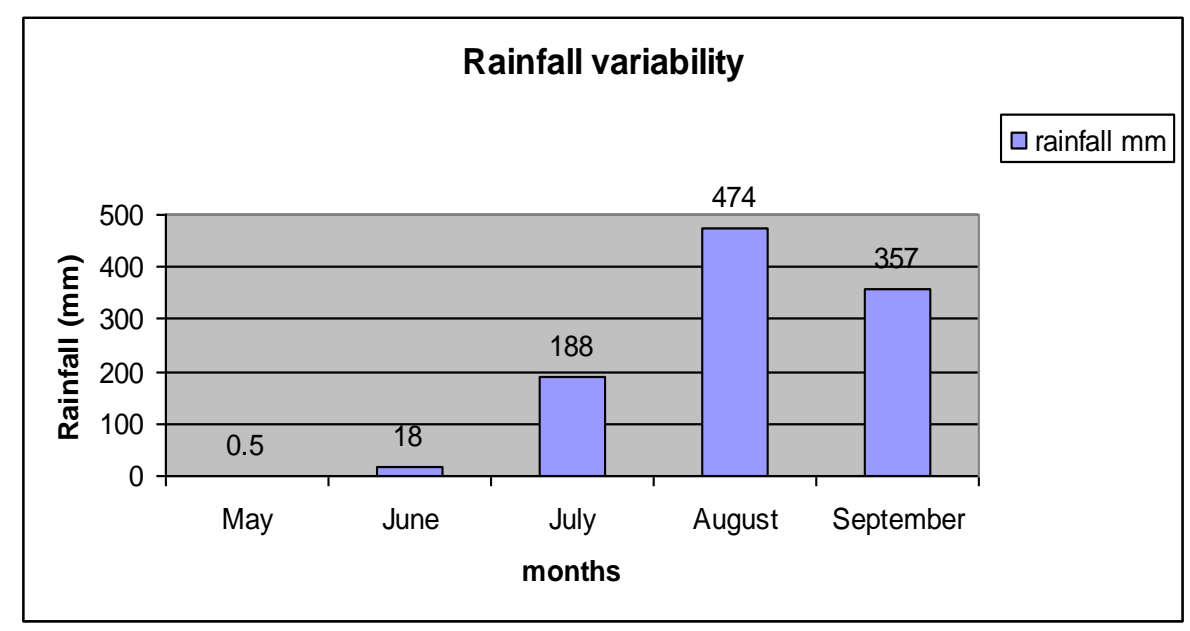

Figure 1 Rainfall variability trend

Table 1 Socioeconomics and frequency distribution of FFS farmers

\begin{tabular}{|l|l|l|}
\hline variables & frequency & Valid \% \\
\hline Education & 4 & 20 \\
\hline illiterate & 5 & 25 \\
\hline khalwa & 6 & 30 \\
\hline elementary & 6 & 15 \\
\hline primary & 3 & 10 \\
\hline secondary & 2 & 100 \\
\hline Total & 20 & \\
\hline Farm size & \multicolumn{2}{|l|}{} \\
\hline Less than 1 feddan & 2 & 10 \\
\hline $1-2$ feddan & 10 & 50 \\
\hline 3-4 feddan & 6 & 30 \\
\hline More than 4 feddan & 2 & 10 \\
\hline Total & 20 & 100 \\
\hline occupation & \multicolumn{2}{|l}{} \\
\hline farmer & 16 & 80 \\
\hline Farmer/pity trader & 4 & 20 \\
\hline & \multicolumn{2}{|l|}{} \\
\hline
\end{tabular}




\begin{tabular}{|l|l|l|}
\hline Total & 20 & 100 \\
\hline Extension services on wheat technologies & 18 & 90 \\
\hline yes & 2 & 10 \\
\hline no & 2 & 100 \\
\hline Total & 20 & \\
\hline Experience in wheat production & 8 & 40 \\
\hline Yes & \multicolumn{2}{|l|}{} \\
\hline No & 12 & 60 \\
\hline Total & 20 & 100 \\
\hline Perception on improved wheat & \multicolumn{2}{|l|}{} \\
\hline Resistant to water logging and high rain fall & 8 & 40 \\
\hline Resist insects & 4 & 20 \\
\hline High yielded & 6 & 30 \\
\hline Low yielded & 2 & 10 \\
\hline Total & 20 & 100 \\
\hline
\end{tabular}

Source: Author 2020

Table 2 Crop productivity trend

\begin{tabular}{|l|l|l|l|l|}
\hline Crop/variety & variety & Area m2 & Yield kg/*feddan & \% change \\
\hline Wheat & Zakia & 4200 & 655 & 54 \\
\hline Wheat & Nillin & 4200 & 626 & 48 \\
\hline Wheat & local & 4200 & 424 & \\
\hline
\end{tabular}

Source: Author, $2020, * 1$ feddan $=0.42$ hectare

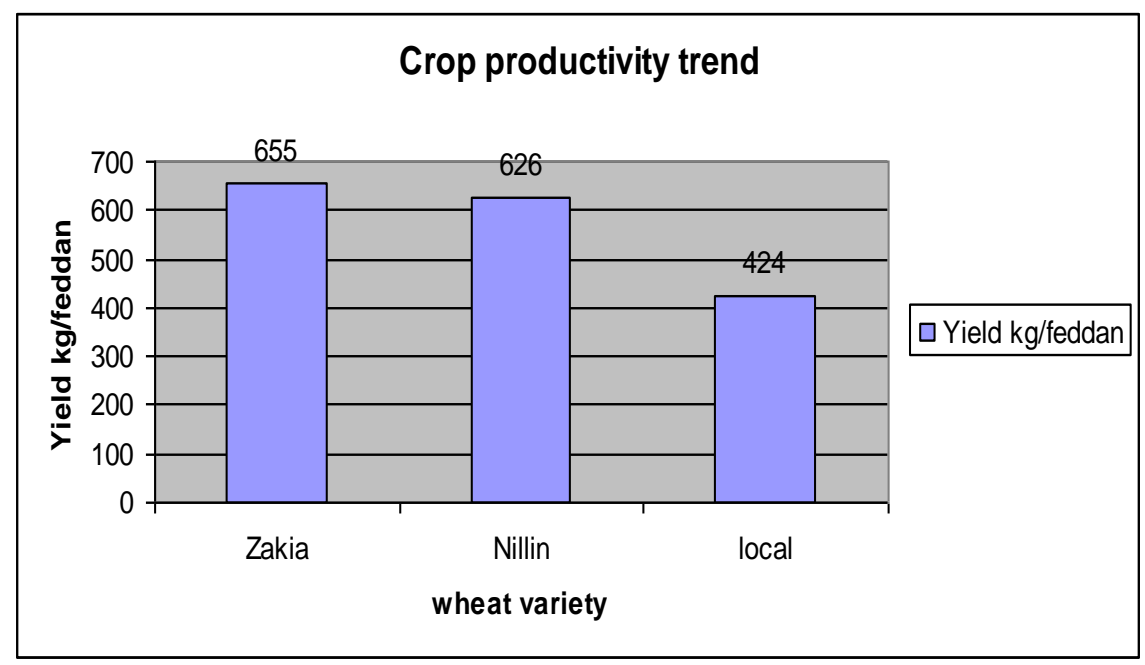

Figure 2 crop productivity trends 
Table 3 Partial crop budget

\begin{tabular}{|l|l|l|l|}
\hline Operation costs & *SDG/*feddan & \multicolumn{2}{l|}{} \\
\hline 1.0 Costs & Zakia & Nillin & Local \\
\hline Land preparation & 3000 & 3000 & 3000 \\
\hline seeds & 8000 & 9000 & 9000 \\
\hline planting & 2100 & 2100 & 1000 \\
\hline Weeding & 9000 & 9000 & 2500 \\
\hline intercedes & 1500 & 1500 & 0 \\
\hline Harvesting & 4000 & 3500 & 2000 \\
\hline Threshing & 2700 & 2500 & 1000 \\
\hline Sacks & 600 & 600 & 400 \\
\hline Total variable costs & 30,900 & 31,200 & 18,900 \\
\hline 2.0 Returns & & & \\
\hline Yield kg/fed & 655 & 626 & 424 \\
\hline Adjusted yield kg/fed. & 524 & 501 & 339 \\
\hline Price SDG/ kg & 100 & 100 & 100 \\
\hline Gross Field benefits & 52,400 & 50,100 & 33,900 \\
\hline Net returns (2-1) & 21,500 & 18,900 & 15,000 \\
\hline
\end{tabular}

Source: Author, $2020,{ }^{*} \mathrm{SDG}=$ Sudanese pound, ${ }^{*} 1$ feddan $=0.42$ hectare

\section{Conclusion}

This study was conducted in Nertiti locality of Central Darfur State (CDS) during 2020/2021 rainy season in order to enhance rainy wheat productivity through technology validation and dissemination. Rainfall variation negatively affect crop yield. Socioeconomic factors and frequency distribution noted that farm size and education levels play a critical role in agricultural sustainability and most of farmer's income obtained from agriculture. It was visible also experience in agricultural farming is very important in crop management in general and particularly in wheat yield potentiality. Improved wheat had great potentiality in yield and net returns versus other tested varieties. Partial crop budget explored that all treatment financially gave positive net returns which indicate farmer profitability from wheat production.

\section{Compliance with ethical standards}

\section{Acknowledgments}

I would like to thanks WJARR staff for giving me this opportunity for publishing my research article. My thanks also is due to all my co-authors for their help and valuable comments.

\section{Disclosure of conflict of interest}

There is no conflict of interest recorded by authors

\section{References}

[1] Ahmed A. Challenges of agricultural technology transfer and productivity increase in the Sudan. Research Gate. World association for sustainable development (WASD). International Journal of Technology Policy and Management. 2004. 
[2] Assefa S, Tadese W, Bishaw Z. Wheat production and breeding in Sub-Saharan Africa Challenges and opportunities in the face of climate change. International Journal of Climate Change Strategies and Management press. 2019; 11(5).

[3] Hassan TA,sabahelkheir AS. Cereal crop diversification and food security in central Darfur state-Sudan. University of Zalingei, Faculty of Agriculture press. Research gate. 2015; 373.

[4] hassan TA, Suliman SE, Dawoud AA. SOCIO-ECONOMIC FACTORS AFFECTING INCOME GENERATING ACTIVITIES OF POOR WOMEN ENTERPRISES IN ZALINGEI-SUDAN. Department of Agricultural Economics, Faculty of Agriculture, University of Zalingei, Zalingei, Central Darfur State, Sudan press. Journal of Agricultural and Biological Science. 2015; 10(11).

[5] Mahgoub F. Current Status of Agriculture and Future Challenges in Sudan. NORDISKA AFRIKAINSTITUTET, UPPSALA. Current African. 2014; 57.

[6] Manikandan S. Frequency distribution. Department of Pharmacology, Indira Gandhi MedicalCollege and Research Institute, Kadirkamam, Puducherry, India. Journal of Pharmacology andPharmacotherapeutics. January-March 2011; 2(1): 54.

[7] Ren C, Liu S, Grinsven HV, Reis S, Jin S, Liu H,Gu B. The impact of farm size on agricultural sustainability. Journal of Cleaner Production. February 2019.

[8] Tigner R. Partial Budgeting: A Tool to Analyze Farm Business Changes. Lowa State University,Nebraska, extension educator. 2018; 1. 